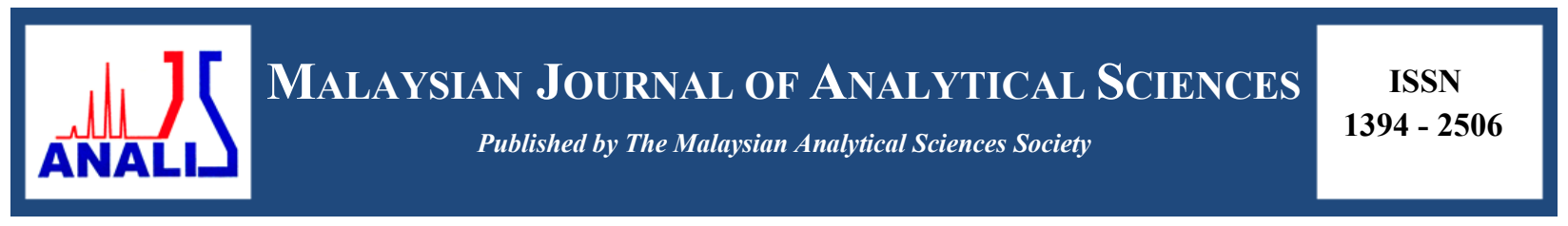

\title{
SUGARS, MINERALS COMPOSITION AND METAL ION CHELATING ACTIVITY OF Arenga pinnata SYRUP USING VACUUM EVAPORATION
}

\author{
(Komposisi Gula, Mineral dan Aktiviti Ion Logam Pengkelat daripada Sirap Arenga pinnata \\ Mengunakan Proses Vakum Penyejatan)
}

\author{
Nurul Janah Yunos ${ }^{1 *}$, Alawi Sulaiman ${ }^{1}$, Nor Azma Yusuf ${ }^{1}$, Dzil Razman Ghazali ${ }^{2}$ \\ ${ }^{1}$ Faculty of Plantation and Agrotechnology, \\ Universiti Teknologi MARA, 40450 Shah Alam, Selangor Darul Ehsan, Malaysia \\ ${ }^{2}$ Balung Plantation \\ Wisma Sabah, Jalan Tun Razak, 88817 Kota Kinabalu, Malaysia \\ *Corresponding author: janahyunos23@gmail.com
}

Received: 4 December 2016; Accepted: 1December 2017

\begin{abstract}
Palm saps harvested from Arenga pinnata tree which typically known as sweet natural beverage were produced into palm sugars using three different production methods of open pan cooking, freeze dry and vacuum evaporation. Sugars and minerals composition such as sucrose, glucose, fructose, magnesium, potassium, sodium and phosphorus were determined. An iron chelating activity was performed to determine the antioxidant activity of different production methods of palm sugars which related to the ability of chelating the transition metal ions. Results showed that all production methods of palm sugars obtained significantly $(\mathrm{p}<0.05)$ different amounts of sugars and minerals. There were significantly $(\mathrm{p}<0.05)$ different in ion chelating activity in different production methods of palm sugars. Vacuum evaporated palm syrup exhibited the highest ability in chelating ferrous ion and the vacuum evaporator dominated the highest percentage of chelating ions at $28.20 \%$ followed by freeze dryer at $26.31 \%$ and open pan at $12.75 \%$, respectively. From the results, slow and controlled temperature by vacuum evaporation could be a promising approach that capable to preserve the ion binding capacity of palm syrup which related in antioxidant activity.
\end{abstract}

Keywords: antioxidant, Arenga pinnata, freeze dry, open pan cooking, vacuum evaporation

\begin{abstract}
Abstrak
Air nira yang dituai daripada pokok Arenga pinnata yang dikenali sebagai air manisan semulajadi telah dijadikan sebagai produk gula kabung dengan menggunakan tiga kaedah iaitu secara tradisi menggunakan kayu api diatas kuali terbuka, dan dua teknologi moden iaitu pembekuan kering dan vakum penyejatan. Komposisi gula dan mineral seperti sukrosa, glukosa, fruktosa, magnesium, potassium, sodium dan fosforus telah ditentukan. Aktiviti ion logam pengkelat telah dikaji untuk menentukan aktiviti antioksidan kepada ketiga-tiga pengeluaran gula kabung yang berkaitan dengan keupayaan peralihan ion logam pengkelat. Hasil kajian mendapati ketiga-tiga pengeluaran gula kabung adalah signifikan $(\mathrm{p}<0.05)$. Gula kabung dari pengeluaran vakum penyejatan menunjukkan hasil paling tinggi iaitu pada $28.20 \%$ diikuti oleh pembekuan kering pada $26.31 \%$ dan pengeluaran secara tradisi iaitu $12.75 \%$. Oleh yang demikian, hasil menunjukkan pengeluaran gula kabung yang menggunakan vakum penyejatan secara perlahan dan suhu terkawal boleh menjadi pendekatan yang mampu memelihara kapasiti mengikat ion yang berkaitan dengan ketinggian aktiviti antioksidan.
\end{abstract}

Kata kunci: antioksidan, Arenga pinnata, pembekuan kering, kuali terbuka, vakum penyejatan 


\section{Introduction}

Palm sap or commonly known as Nira Kabung is harvested from Arenga pinnata tree which widely grown in tropical region and humid climate. This palm tree belongs to family Arecaceae, which originated from the tropical south Asia and South-east Asia. Some studies showed that A. pinnata could reach altitude from 20 meters to 1400 meters above sea level with a diameter trunk of $65 \mathrm{~cm}$ approximately [1]. In fact, a single tree of $A$. pinnata could yield up to 6 litres of saps per day. It is widely reported that the environment conditions where $A$. pinnata grows affects sugar, protein, and mineral contents in the tree [2].

In Malaysia, A. Pinnata tree is commonly grown in the forest by some local entrepreneurs for economic purposes. Local community usually collect the palm saps by tapping process using bamboo cut collectors before being cooked and turn to palm sugar block. Many studies reported that the production of palm saps from A. pinnata tree could contribute to the socioeconomic growth in local areas for extra household income. According to Schoneman [3], the palm sugar is the first palm that used to be the one of the economic purposes in trading process. The community of West Java Indonesia has utilized this tree to produce to produce palm sugar block as a household income. Research study showed that that crucial of palm sugar products is capable four to eight times more productive compared to sugar cane product [4].

Normally, the concentrated palm sugar was produced by traditional cooking method using firewood before being moulded into sugar blocks using bamboo fragments. However, the cooking temperature could be associated with loss of nutrients in the palm sugar. Other study reported that the heating temperature was the most influential factor for determining the palm sugar quality [5]. Moreover, the non enzymatic browning reaction which resulted from reducing sugars and amino acids reaction also contributed to the changes of palm sugar quality. Therefore, the three different production methods of palm sugars were evaluated for their chemical compositions.

The present study discusses the sugars properties (sucrose, glucose and fructose) and mineral properties (magnesium, potassium, sodium and phosphorus) of open pan cook, freeze dried and vacuum evaporated palm sugars. Currently, there is no research has been reported regarding the metal ion chelating activity of $A$. pinnata sugar. Hence this study revealed the effects of different production methods of palm sugars towards chelating ability that relate to the antioxidant activity.

\section{Sample preparation}

\section{Materials and Methods}

Three different production methods of palm sugars by open pan cooking, freeze drying and vacuum evaporation which were obtained from Balung Plantation, Sabah. Respectively, the palm sugars were formed into concentrated palm sugar block by open pan cooking, powder formed by freeze dryer and syrup formed by vacuum evaporator.

\section{Determination of sugars}

High Performance Liquid Chromatography (HPLC) (1200 Series, Agilent Technologies, United States) was used to determine the type of sugars content in palm sugars. Data was obtained at $195 \mathrm{~nm}$ by using refractive index detector. The system was maintained in controlled room temperature. Mobile phase of pure water and acetonitrile (50:50) was freshly prepared and sonicated under ultrasonic bath for 30 minutes prior to HPLC analysis. A flow rate of $1.5 \mathrm{ml} / \mathrm{min}$ and injection volume of $20 \mu \mathrm{L}$ was used. Sample analysis was performed using C-18 column. The samples solution was made up with $50 \mathrm{~mL}$ using pure water and acetonitrile (50:50) for every $5.0 \mathrm{~g}$ of palm sugar samples. All samples must be filtered through a $0.45 \mu \mathrm{m}$ filter prior to injection. Sugar standards were diluted using $100 \mathrm{~mL}$ using pure water and acetonitrile (50:50) for every $3.0 \mathrm{~g}$ of D-glucose, $3.8 \mathrm{~g}$ of D-fructose and $0.6 \mathrm{~g}$ sucrose. The prepared standard solutions were sonicated for 30 minutes in ultrasonic bath to remove all the air bubbles.

\section{Determination of minerals}

Calcium, phosphorus, sodium and potassium content were analyzed using inductively coupled plasma mass spectrometry (ICP-MS) (7300 DV, Agilent Technologies, United States). The method was modified as described by Ajai et al. [6]. All the palm sugar samples were weighed about $5 \mathrm{~g}$ and dissolved in $10 \mathrm{~mL} 0.1 \mathrm{M} \mathrm{HNO}_{3}$. The 
samples mixtures were cautiously heated under fume hood. After that, the samples solutions were filtered using Whatman No.1 filter paper. The samples filtrates were diluted using $50 \mathrm{~mL}$ of pure water.

\section{Determination of metal ion chelating activity}

Metal chelating activity was determined using modified method [7]. Palm sugar samples were diluted using $10 \mathrm{~mL}$ of pure water. An amount $500 \mu \mathrm{L}$ of diluted samples were mixed with $500 \mu \mathrm{L}$ of $2 \mathrm{mM} \mathrm{FeCl}_{2}$ and $0.2 \mathrm{~mL}$ of $5 \mathrm{mM}$ ferrozine solution. After 10 minutes, the absorbance reading was measured spectrophotometrically at $562 \mathrm{~nm}$ using UV-Vis spectrophotometer (ST-UV8000, Sastec, Germany). The percentage of inhibition of ferrozine-Fe2 ${ }^{+}$ complex formation was expressed by using the equation: by [1-(test sample absorbance/blank sample absorbance)] $\mathrm{x} 100$.

\section{Statistical analysis}

Data were analyzed to analysis of variance (ANOVA) using Statistical Package for Social Science (SPSS version 19.0). Results were performed in triplicate and the results were expressed as the mean values and standard deviation. The results of significance differences were determined by Tukey's (HSD) post hoc test $(\mathrm{p}<0.05)$.

\section{Results and Discussion}

Tabulated results were obtained in determining the sugar and mineral compositions in three different production methods of palm sugars. Sucrose, glucose and fructose content of palm sugars are shown in Table 1 and the results showed significance difference $(\mathrm{p}<0.05)$ in sugars content. The major sugar present in all palm sugars was sucrose. Freeze dry production method showed the highest sucrose content followed by open pan and vacuum evaporator production methods. As shown in Table 1 the freeze dried palm sugar exhibited the highest sugars content of sucrose, glucose and fructose compared to vacuum evaporated palm sugar. Food and Nutrition Research InstituteDepartment of Science and Technology of Philippines had conducted the study on the sugar composition of palm sugar block (Kaong sugar). The data revealed that the palm sugar had the highest sucrose content at $95.80 \%, 0.37 \%$ of glucose and $0.80 \%$ of fructose. This is in contrast to the results obtained for this study for open pan cooking production method. However, these findings may be due to the different techniques used for open pan cooking during the making of palm sugars. Besides, the time storage of palm sugars also could contribute to the various sugars content. With respect to the results obtained, the vacuum evaporation production method which was maintained at low and controlled-temperature showed low inversion of sucrose during the production process. It is interesting to note that as the temperature increases the sucrose content in the palm sugar will break down into glucose and fructose. This present study is similar to other researcher where the palm sugar syrup heated by vacuum evaporator could retain more sucrose content from further inverted compared to palm syrup heated by open pan [5].

Table 1. Types of sugar content of palm sugar samples

\begin{tabular}{llll}
\hline Production Methods & Sucrose (\%) & Glucose (\%) & Fructose (\%) \\
\hline Open pan & $60.23 \pm 0.26^{\mathrm{a}}$ & $3.83 \pm 0.05^{\mathrm{a}}$ & $4.67 \pm 0.05^{\mathrm{a}}$ \\
Freeze dry & $61.20 \pm 0.17^{\mathrm{b}}$ & $6.53 \pm 0.05^{\mathrm{b}}$ & $6.77 \pm 0.05^{\mathrm{b}}$ \\
Vacuum evaporation & $50.37 \pm 0.13^{\mathrm{c}}$ & $3.50 \pm 0.09^{\mathrm{c}}$ & $3.27 \pm 0.05^{\mathrm{c}}$ \\
\hline
\end{tabular}

Data presented as mean $\pm \mathrm{SD}$ of triplicate results. The different superscript letters represented the significant different $(\mathrm{p}<0.05)$

Table 2 represents the results of minerals composition in three different production methods of palm sugars. The mineral elements have been evaluated using inductively coupled plasma spectrometry (ICP-MS). Generally, ICPMS application is a powerful tool in detection of metals and non-metals especially in solution. This tool uses Argon gas to move the sample vapour into a chamber under high vacuum condition where both of the samples and gas are heated such that elements will give off a characteristic wavelength of light [8]. 
Nurul Janah et al: SUGARS, MINERALS COMPOSITION AND METAL ION CHELATING ACTIVITY OF

Arenga pinnata SYRUP USING VACUUM EVAPORATION

Table 2. Types of mineral content of palm sugar sample

\begin{tabular}{lcccc}
\hline $\begin{array}{l}\text { Production } \\
\text { Methods }\end{array}$ & $\begin{array}{c}\text { Magnesium } \\
(\mathbf{m g} / \mathbf{k g})\end{array}$ & $\begin{array}{c}\text { Potassium } \\
\mathbf{( m g} / \mathbf{k g})\end{array}$ & $\begin{array}{c}\text { Calcium } \\
\mathbf{( m g} / \mathbf{k g})\end{array}$ & $\begin{array}{c}\text { Phosphorus } \\
(\mathbf{m g} / \mathbf{k g})\end{array}$ \\
\hline Open pan & $289.22 \pm 0.88^{\mathrm{a}}$ & $6412.8 \pm 56.41^{\mathrm{a}}$ & $77.76 \pm 0.60^{\mathrm{a}}$ & $1536.60 \pm 15.62^{\mathrm{a}}$ \\
Freeze dry & $264.02 \pm 0.64^{\mathrm{b}}$ & $5569.70 \pm 141.39^{\mathrm{b}}$ & $68.83 \pm 0.56^{\mathrm{b}}$ & $1381.30 \pm 21.90^{\mathrm{b}}$ \\
Vacuum evaporator & $207.82 \pm 0.67^{\mathrm{c}}$ & $4315.30 \pm 104.54^{\mathrm{c}}$ & $108.65 \pm 0.36^{\mathrm{c}}$ & $8645.20 \pm 15.72^{\mathrm{c}}$ \\
\hline
\end{tabular}

Data presented as mean $\pm \mathrm{SD}$ of triplicate results. The different superscript letters represented the significant different $(\mathrm{p}<0.05)$

The above data shows that there were significance differences $(\mathrm{p}<0.05)$ in magnesium, potassium, calcium and phosphorus content in all palm sugar samples. The vacuum evaporated palm sugar exhibited the lowest magnesium and potassium content. However, the vacuum evaporated palm sugar showed the highest content in phosphorus content compared to other production methods. Previous study of maple syrup showed the most of common minerals found were potassium and calcium but low amount in magnesium and phosphorus [9]. All the mentioned minerals definitely play the vital roles in regulating the physiological and biochemical in human body. Other reseacher reported that the influence of other factors such as geographical environment, soil chemistry, viticulture practices and processing methods need to be understood [10]. Other study revealed that the seasons and altitudes had contributed a significant effects on magnesium, potassium and calcium content in A. pinnata sap from North Sulawesi Province, Indonesia [2]. Comparing with the study obtained by this author, there were substantial increases in the concentration of minerals elements in the palm sugars after being applied to different production methods. During the process, the palm saps were concentrated gradually into browning palm sugar due to increase in sugar content as well as increased in minerals and others chemicals composition in the palm sugar that reflects from the heating processes.

Other study showed that, the distinctive mineral composition of the date palm heart could be because of the bioaccumulation capabilities in assimilating and accumulating minerals from the soil tree [11,12]. Also, the various results acquired between the three production methods of palm sugars might be attributed from the environmental factors such as pedoclimatic and atmospheric conditions. The varied in extraction technique could also affluent the results obtained.

Figure 1 represents the chelating $\mathrm{Fe}^{2+}$ ions ability in three different production methods of palm sugars. Undoubtedly, the results obtained showed that all production methods of palm sugars were significantly $(\mathrm{p}<0.05)$ different and the vacuum evaporator dominated the highest percentage of chelating ions at $28.20 \%$ followed by freeze dryer at $26.31 \%$ and open pan at $12.75 \%$, respectively. Similar results were found in the palm dates syrup at $250 \mu \mathrm{g}$ acquired about $28.70 \%$ in chelating $\mathrm{Fe}^{2+}$ ions [13] . In recent study, the metal chelating agents function as inactivate metal ions $\left(\mathrm{Fe}^{2+}\right)$ besides can reduce the redox potential where the agents are classified as effective secondary antioxidants [14].

In general, antioxidants can be described as reductants which reduced the oxidation reaction by inactivated the oxidant [15]. Complementary to this, an iron commonly act as an initiator of unwanted oxidative reactions in lipids, proteins and other cellular components which can be simplified as free radicals generator [13]. According to Gulcin et al., $\mathrm{Fe}^{2+}$ ions are able to create the formation and propagation of radical reactions and non-reactive radicals by transferring the single electrons [16]. Therefore, the results obtained declared that the presence of active compounds in the palm sugars could inhibit the metal ions $\left(\mathrm{Fe}^{2+}\right)$. In regards to this, the results signify the vacuum evaporation production method could preserve the active compounds that represent the capability to chelate the $\mathrm{Fe}^{2+}$ ions compared to the other production methods. This is might be related with slow and controlled-temperature of heating method that slows down the rapid loss of active compounds in the palm sugars during the processes. It was also confirmed that the results obtained from ion chelating activity of $A$. pinnata palm sugar was the first being reported. 


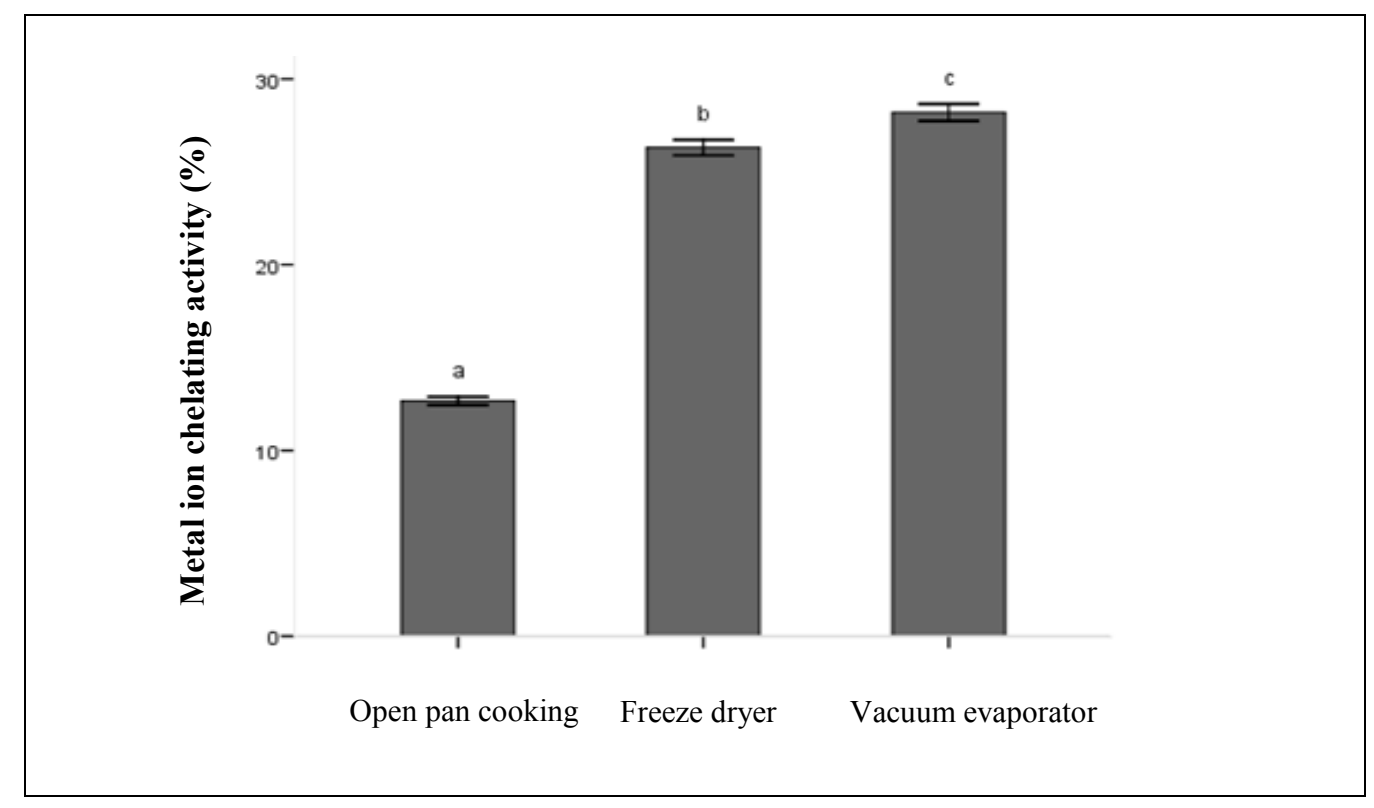

Figure 1. Metal ion chelating activity of different production methods of palm sugar. Data presented as mean \pm SD of triplicate results. The different letters represented the significant different $(p<0.05)$

\section{Conclusion}

The present study showed that the different production methods of palm sugars demonstrated the results variability in sugars and minerals content. Also, this study suggested that the ion chelating activity of the palm sugar was largely influenced by the heating method. The slow and controlled temperature of vacuum evaporation could retain the higher antioxidant activity in their palm syrups. It is expected that the findings of this study will be useful in determining the optimum heating temperature in palm syrup of vacuum evaporation production method for optimum antioxidant preservation.

\section{Acknowledgement}

The authors would like to thank the Universiti Teknologi MARA (UiTM) for the grant of Research Entity Initiative (REI): 600-RMI/DANA 513/REI (8/2013), Fundamental Research Grant Scheme (FRGS): 600-RMI/FRGS 5/3(84/2015) and Postgraduate Supporting Fellowship (ZAMALAH): 600-RMI/DANA 5/3/PSF (10/2015). Also, we would like to thank the Balung Plantation, Sabah for providing the palm sugars samples.

\section{References}

1. Safari, A. (1995). Making techniques palm sugar. http://docsdrive.com/pdfs/ansinet/pjn/2015/531-534.pdf. [Access online 13 February 2016].

2. Lantemona, H., Abadi, A. L., Rachmansyah, A. and Pontoh, J. (2013). Impact of altitude and seasons to volume, brix content, and chemical composition of aren sap in north Sulawesi. IOSR Journal of Environmental Science, Toxicology and Food Technology, 4: 42-48.

3. Schoneman, J. P. (2010). Overview of uses of palms with an emphasis on old world and Australasian medicinal uses. Doctoral dissertation, University of Texas, USA.

4. Ismail, L. (2012). Acoustic and durability performances of Arenga Pinnata panel. Doctoral dissertation, Universiti Tun Hussein Onn Malaysia, Malaysia.

5. Naknean, P., Meenune, M. and Roudaut, G. (2009). Changes in physical and chemical properties during the production of palm sugar syrup by open pan and vacuum evaporator. Asian Journal of Food and Agro-industry, 2(4): 448-456.

6. Ajai, A. I., Ochigbo, S. S., Abdullahi, Z. and Anigboro, P. I. (2014). Determination of trace metals and essential minerals in selected fruit juices in Minna, Nigeria. International Journal of Food Science, 2014: 1-5. 
7. Decker, E. A., and Welch, B. (1990). Role of ferritin as a lipid oxidation catalyst in muscle food. Journal of Agricultural and Food Chemistry, 38(3): 674-677.

8. University of Massachusetts Amherst (2011). Chemical analysis of mineral analysis. http://www.geo.umass.edu/courses/geo311/min\%20chem\%20anal ysis\%20lecture.pdf. [Access online 23 February 2016].

9. Heiligmann, R. B., Koelling, M. R. and Perkins, T. D. (2006). North American maple syrup producers manual. Ohio State University Extension Bulletin, 856: 298-299.

10. Rupasinghe, H. P. V. and Clegg, S. (2007). Total antioxidant capacity, total phenolic content, mineral elements, and histamine concentrations in wines of different fruit sources. Journal of Food Composition and Analysis, 20(2): 133-137.

11. Damodaran, D., Shatty, K.V. and Mohan, B.R. (2013). Effect of Chelaters on Bioaccumulation of Cd (II), $\mathrm{Cu}(\mathrm{II}), \mathrm{Cr}(\mathrm{VI}), \mathrm{Ph}(\mathrm{II})$ and $\mathrm{Zn}(\mathrm{II})$ in Galerina vittiformis from Soil. International Biodeterioration and Biodegradation, 85: 182-188.

12. Kumaravel, S. and Alagusundaram, K. (2014). Determination of mineral content in Indian spices by ICP-OES. Oriental Journal of Chemistry, 30(2): 631-636.

13. Al-Mamary, M., Al-Habori, M. and Al-Zubairi, A. S. (2014). The in vitro antioxidant activity of different types of palm dates (Phoenix dactylifera) syrups. Arabian Journal of Chemistry, 7(6): 964-971.

14. Kchaou, W., Abbès, F., Blecker, C., Attia, H. and Besbes, S. (2013). Effects of extraction solvents on phenolic contents and antioxidant activities of Tunisian date varieties (Phoenix dactylifera L.). $\quad$ Industrial Crops and Products, 45: 262-269.

15. Phisut, N. and Jiraporn, B. (2013). Characteristics and antioxidant activity of Maillard reaction products derived from chitosan-sugar solution. International Food Research Journal, 20(3): 1077-1085.

16. Gulcin, I., Elmastas, M. and Aboul-Enein, H. Y. (2007). Determination of antioxidant and radical scavenging activity of Basil (Ocimum basilicum L. Family Lamiaceae) assayed by different methodologies. Phytotherapy Research, 21(4): 354-361. 